\title{
Typhoid fever: issues in laboratory detection, treatment options \& concerns in management in developing countries
}

\author{
Balaji Veeraraghavan*,1, Agila K Pragasam¹, Yamuna D Bakthavatchalam \& Ravikar Ralph² \\ ${ }^{1}$ Department of Clinical Microbiology, Christian Medical College, Vellore 632004, Tamil Nadu, India \\ ${ }^{2}$ Department of Medicine, Christian Medical College, Vellore 632004, Tamil Nadu, India \\ *Author for correspondence: Tel.: +91 9442210 555; vbalaji@cmcvellore.ac.in
}

Multidrug-resistant Salmonella enterica subsp. enterica serovar Typhi (resistant to ampicillin, chloramphenicol and cotrimoxazole), was significantly reduced with the increased usage of fluoroquinolones and azithromycin. This has led to declining multidrug resistance rates in India with increasing ciprofloxacin nonsusceptibility rates and clinical failures due to azithromycin. However, for the available agents such as ceftriaxone, azithromycin and fluoroquinolones, the dose and duration for treatment is undefined. The ongoing clinical trials for typhoid management are expected to recommend the defined dose and duration for better clinical outcome. We made an attempt to summarize the issues in laboratory detection, treatment options and responses, and the concerns in clinical practice seen in the developing countries.

Lay abstract: Typhoid fever is an important cause of mortality in developing countries and is a major public health concern. Cephalosporins or azithromycin are the drugs of choice for treating infection caused by the reduced fluoroquinolone susceptibility of $S$. Typhi. Emergence of cephalosporin resistance in $S$. Typhi and azithromycin-associated clinical and microbiological failure is of significant concern in developing countries. An approach of cephalosporin-azithromycin combination therapy has been suggested, which could be a potential alternative in treating uncomplicated $S$. Typhi infection in endemic areas. This review summarizes the field so far.

First draft submitted: 10 January 2018; Accepted for publication: 26 April 2018; Published online: 26 June 2018

Keywords: azithromycin $\bullet$ cefixime $\bullet$ ceftriaxone $\bullet$ Salmonella Typhi

Typhoid fever is caused by the bacterium Salmonella enterica subsp. enterica serovar Typhi. It is mainly due to the inadequate access to safe water and sanitation, which is a major problem in developing countries. The global burden of typhoid fever was estimated to be 12 million cases and 130,000 deaths in the year 2010. It exceeded 100 cases per 100,000 people/year in South East Asian countries, and has especially high burden rates in India. A recent systematic review and meta-analysis estimated the prevalence of laboratory confirmed typhoid and paratyphoid cases in India to be 9.7 and $0.9 \%$, respectively [1].

In endemic areas, patients with typhoid are considered as outpatients and treated with oral antibiotics, with hospital admission required only for complicated cases. Important concerns about typhoidal cases include relapse, which may complicate the illness; and fecal carriage, which can become chronic and may lead to continued transmission [2]. In late 1980s, 2-3 weeks of chloramphenicol was the treatment of choice for typhoid fever [3]. Subsequently, an increased number of strains with plasmid-mediated multidrug resistance (MDR) to chloramphenicol, ampicillin and cotrimoxazole are reported. Fluoroquinolone (ciprofloxacin and ofloxacin) has become the favored drug following the emergence of strains with MDR [4]. Although fluoroquinolones are superior to cephalosporins, the spread of strains with decreased susceptibility to ciprofloxacin has limited their effectiveness, particularly in Asia [5]. Extended spectrum cephalosporins (ceftriaxone and cefixime) and azithromycin are suitable alternatives for reduced fluoroquinolone susceptible $S$. Typhi [2,6]. The combinations of cephalosporin and azithromycin are quite frequently used to treat the patients who failed to respond promptly. The general rationale for their use is for 
broadening the spectrum of antimicrobial activity, to exploit the potential synergy between the drugs and reduce the probability of resistance development during course of treatment $[7,8]$.

Although typhoid continues to be seen in large numbers, documented typhoid cases are reducing in recent years. The definitive diagnosis of typhoid fever requires a confirmed diagnosis based on the blood or bone marrow culture. However, blood culture has several limitations including amount of blood required (2-4 $\mathrm{ml}$ from toddlers and $10-15 \mathrm{ml}$ from adolescents and adults) due to low levels of bacteremia and prior antibiotic use [9]. Furthermore, such laboratory facilities are limited or nonexistent in many Asian countries. An accurate and rapid diagnosis of typhoid fever improves the management of patients with appropriate antibiotic therapy. The sensitivity of blood culture is estimated to be between 40 and 60\% [10]. Partly, this could be due to increased use of oral antibiotics prescribed in the communities without laboratory investigations.

This review summarizes the challenges in the laboratory diagnosis of typhoid fever and the current situation of MDR S. Typhi, and further explores the problem of antimicrobial resistance in these infections, management issues in clinical practice and combination treatment options for typhoidal Salmonella.

\section{Challenges in detection of typhoidal Salmonella}

Although there is a decline in the incidence of $S$. Typhi, the true isolation of $S$. Typhi from blood cultures is still challenging [11]. Patients who are suspected of typhoid fever are given antimicrobials in the community and later referred to the tertiary care hospital for blood cultures. In India, ofloxacin-based combinations such as ofloxacin plus cefixime or ofloxacin plus azithromycin are most abundantly used and are available over the counter. According to the Center for Disease Dynamics, Economics \& Policy, the consumption rate of cephalosporin has increased from 1887 to 7269 standard units/ 1000 people from 2000 to 2014, respectively. Similarly, macrolide usage has increased from 1166 to 1862 standard units/1000 people from 2000 to 2014, respectively. Meanwhile, fluoroquinolone usage ranged about 2608 to 2661 standard units/1000 population from 2000 to 2014 , respectively [12]. This indicates the abundant usage of cephalosporins, fluoroquinolones and macrolides in the Indian setting. Owing to this, patients who have taken a cephalosporin-based combination (cefixime plus ofloxacin) are likely to exhibit a false-negative blood culture. It is, therefore, imperative to obtain a blood culture before initiating the antimicrobial therapy as the presence of antimicrobials could reduce the yield of $S$. Typhi in the blood cultures. To counteract this, commercial blood culture systems have incorporated synthetic resin molecules in the bottles to neutralize the antimicrobials present. Previous studies have demonstrated the neutralization of antimicrobials by the use of resin-based culture bottles [13-15]. However, certain antimicrobials have not been neutralized by the resins, hence this remains a limitation. This includes the fluoroquinolones and cephalosporins, which are the commonly used drugs in the community for suspected typhoid fever. Importantly, no published studies on the recovery of $S$. Typhi in blood cultures collected from patients with prior antibiotics were found.

Diagnosis of typhoid fever by conventional blood culture is challenging and time consuming as it takes about 24-48 h, after which the culture bottle flags positive. Although it is the gold standard method for detection of $S$. Typhi in the blood, turnaround time plays a significant role in the management. WIDAL slide agglutination test is the second most commonly prescribed test. Yet, poor sensitivity and specificity is a limitation [16]. Due to this, commercial rapid diagnostic tests (RDTs) are of great interest. However, owing to the poor sensitivity and specificity rates, definite detection is still limited. Typhidot-M, TUBEX-TM and Test-it are the three serological-based tests that have been evaluated. Performance of these tests have been shown to be poor and variable due to the high rates of disease burden in Asia, which is endemic for typhoid. In contrast, evaluation done in the Philippines has shown high sensitivity and specificity rates [17]. Among the three tests, TUBEX performance was found better with $78 \%$ of sensitivity and $87 \%$ specificity [18]. Due to these limitations, the WHO has issued no recommendations on the use of commercial RDTs [16]. Although RDT uses serum and urine samples, other than blood, isolation of $S$. Typhi from blood culture and bone marrow still remains the gold standard, as the susceptibility profile of the infected organisms cannot be inferred from serologic-based tests.

\section{MDR Salmonella Typhi}

Approximately 65\% MDR rates were seen during 1990-1992 in India, with 71\% MDR rates in central India and $55 \%$ in southern parts of India [19]. Due to the high rates of MDR strains, the use of ampicillin, chloramphenicol and cotrimoxazole has declined, resulting in the increased use of fluoroquinolones (ofloxacin and ciprofloxacin) [20,21]. This has resulted in the phenomenon of decreased ciprofloxacin susceptibility (DCS) while cephalosporin resistance has begun to rise. Recently, MDR rates have drastically declined and the rates have fallen down from $26 \%$ in 2004 
Table 1. Burden of antimicrobial resistance rates reported in typhoidal Salmonella from Indian studies of past 15 years.

\begin{tabular}{|c|c|c|}
\hline Antibiotic & Salmonella Typhi & Salmonella Paratyphi A \\
\hline Ampicillin $^{\dagger}$ & $5-72 \%$ & $0-74 \%$ \\
\hline Chloramphenicol $^{\dagger}$ & $3-27 \%$ & $0-23 \%$ \\
\hline Cotrimoxazole $^{\dagger}$ & $2.3-35 \%$ & $0-36 \%$ \\
\hline Nalidixic acid & $78-100 \%$ & $63-100 \%$ \\
\hline Ciprofloxacin $\ddagger$ & $0-97 \%$ & $0-100 \%$ \\
\hline Ceftriaxone & $0-4 \%$ & $0-6 \%$ \\
\hline
\end{tabular}

${ }^{\dagger}$ MDR S. Typhi classified based in resistance to ampicillin, chloramphenicol and cotrimoxazole is coming down in the recent years.

¥High rates of ciprofloxacin resistance is due to the revised breakpoints in the CLSI guideline.

Refs: [23-29]

CLSI: Clinical and Laboratory Standards Institute; MDR: Multidrug-resistant.

\begin{tabular}{|c|c|c|c|}
\hline Antibiotic class & Resistance mechanism & AMR genes responsible & Ref. \\
\hline B-lactams (ampicillin) & Enzymatic hydrolysis & bla TEM, bla cTX-M, bla sHV & [30] \\
\hline Chloramphenicol & Enzymatic hydrolysis & cat & [30] \\
\hline $\begin{array}{l}\text { Sulfonamides } \\
\text { (trimethoprim/sulfamethoxazole) }\end{array}$ & Enzymatic hydrolysis & dfrA, sul1 and sul2 & [30] \\
\hline \multirow{2}{*}{$\begin{array}{l}\text { Quinolones (nalidixic acid, } \\
\text { ciprofloxacin,pefloxacin) }\end{array}$} & Drug target alterations (QRDR) & gyrA, gyrB, parC,parE & [31] \\
\hline & Enzymatic hydrolysis (PMQR) & $q n r \mathrm{~A}, q n r \mathrm{~B}, q n r S, \operatorname{aac}\left(6^{\prime}\right)-l b-c r, q e p A$ & [32] \\
\hline Cephalosporins (ceftriaxone, cefixime) & AmpC B-lactamases ESBLs & bla сму, bla ғох b/a стх-м-15 & - \\
\hline Macrolides (azithromycin) & $\begin{array}{l}\text { Enzymatic hydrolysis overexpression of efflux } \\
\text { pumps }\end{array}$ & $\begin{array}{l}\text { ere } A \text {, ere } B, \text { erm } B, \text { mef } A, m p h A, m p h B \text { and } \\
m p h D\end{array}$ & [32-35] \\
\hline
\end{tabular}

ESBL: Extended spectrum beta-lactamase; PMQR: Plasmid-mediated quinolone resistance; QRDR: Quinolone-resistance determining region.

to $1 \%$ at present [20]. A similar picture is noted in Christian Medical College (CMC), Vellore, India, with less than $1 \%$ MDR rates (V. Balaji, Unpublished Data) and at New Delhi [10] and all over India. Furthermore, the Indian Network for Surveillance of Antimicrobial Resistance conducted between 2008 and 2010 has reported less than $5 \%$ of MDR S. Typhi across India [22]. In addition, the burden of antimicrobial resistance reported in the Indian studies are summarized in Table 1. The antimicrobial resistance mechanisms seen in S. Typhi and reported in the literature are mentioned in Table 2.

\section{Fluoroquinolones}

Fluoroquinolones are a class of broad-spectrum antibiotic and are the direct inhibitors of bacterial DNA synthesis. Ciprofloxacin and ofloxacin are currently the drugs of choice for most cases of typhoid fever. These fluoroquinolones have become affordable for use in many resource-limited areas. Ofloxacin was an excellent choice of antibiotic used for treating typhoidal Salmonella, as it has excellent plasma and intracellular penetrations with more bactericidal activity [36]. However, the phenomenon of reduced susceptibility to fluoroquinolones has also been implicated in ofloxacin treatment. For the isolates with an MIC of $\geq 0.25 \mu \mathrm{g} / \mathrm{ml}$, despite prolonged duration and increased dose of therapy, clinical failure has been seen [37]. This was observed with a randomized control trial (RCT) carried out between 1992 and 2001. The study provided evidence for the clinical failure cases of $S$. Typhi when the isolates ofloxacin MIC was $\geq 0.25 \mu \mathrm{g} / \mathrm{ml}$. However, for isolates with an MIC of $\leq 0.125 \mu \mathrm{g} / \mathrm{ml}, 96 \%$ clinical success was observed [37]. Due to the inconsistencies in the cutoffs, the Clinical and Laboratory Standards Institute (CLSI, M100-S23) has removed the disc diffusion breakpoint criteria and recommended MIC testing for determining susceptibility, and revised the susceptible range interpretation from $\leq 2 \mu \mathrm{g} / \mathrm{ml}$ in 2012 to $\leq 0.12 \mu \mathrm{g} / \mathrm{ml}$ in 2013 for ofloxacin and levofloxacin as well [38].

For ciprofloxacin, the CLSI has revised the breakpoints for categorizing the clinical isolates $\leq 0.06 \mu \mathrm{g} / \mathrm{ml}$ as susceptible in 2012 [39]. Clinically, DCS is associated with clinical failure when ciprofloxacin MIC was ranging from 0.12 to $1 \mu \mathrm{g} / \mathrm{ml}$, which is commonly seen in India [23,40]. MDR isolates with decreased ciprofloxacin susceptibility strains in India are on the increase, and this needs continuous monitoring [41]. Earlier, this was missed as the 
dependence was on nalidixic acid resistance (NAR) using disc diffusion testing. Moreover, monitoring NAR was not carried out with ciprofloxacin MIC.

However, in recent times, rising DCS with the sustained decrease in the MDR typhoidal Salmonella has been seen [20]. Similarly, Singhal et al. reported the declining MDR rates with the increased incidence of nalidixic acidresistant, DCS isolates in Northern India [23]. There has been a reported decline in MDR with a parallel increase in DCS among $S$. Typhi. Ampicillin, chloramphenicol or cotrimoxazole are less likely preferred because of longer duration of therapy, threat of re-emergence of resistance, side effects and higher relapse rates.

Quinolone resistance is due to mutations in the quinolone-resistance determining regions of chromosomal genes such as $\operatorname{gyr} A, \operatorname{gyr} B$, $\operatorname{par} C$ and $\operatorname{parE}$ and plasmid-mediated $q n r$, qepA and aacs( 6 )-Ib-cr genes [42]. Studies have reported that plasmid-mediated resistance showed reduced susceptibility to ciprofloxacin (MIC of 0.125$1.0 \mu \mathrm{g} / \mathrm{ml}$ ), which could not be picked up by the nalidixic acid test [43]. Therefore, the CLSI and EUCAST recommend a new screening surrogate marker of pefloxacin $(5 \mu \mathrm{g})$ disc diffusion for detecting both chromosomaland plasmid-mediated resistance. This observation was evidenced by testing of pefloxacin, wherein $80 \%$ of the NAR and ciprofloxacin moderately susceptible isolates were resistant to pefloxacin $[44,45]$. Therefore, pefloxacin testing would ultimately help in the accurate identification of quinolone susceptibility for a better therapeutic success rate.

Gatifloxacin is an inexpensive fluroquinolone antibiotic with an excellent in vitro activity against $S$. Typhi. Gatifloxacin has the lowest MIC with the $\mathrm{MIC}_{50}$ of $0.19 \mu \mathrm{g} / \mathrm{ml}$ against $S$. Typhi, compared with ciprofloxacin and ofloxacin $\left(\mathrm{MIC}_{50}, 0.75 \mu \mathrm{g} / \mathrm{ml}\right)$ [46]. Strikingly, gatifloxacin showed activity against isolates with DCS phenomenon. This is due to the ability of gatifloxacin to evade the point mutations in gyrA (Ser 83 Phe, Asp 87 Gly) contributing for DCS. For isolates included from India, the MIC range was observed to be $0.006-0.25$ and $0.012-0.19 \mu \mathrm{g} / \mathrm{ml}$ for ciprofloxacin and gatifloxacin, respectively [47]. Furthermore, two trials have reported that good clinical response was noted with 7 days of therapy $(10 \mathrm{mg} / \mathrm{kg}$ per day) and suggested gatifloxacin to be more effective than other agents. More importantly, fever clearance time was $92 \mathrm{~h}$ for gatifloxacin, while it was $138 \mathrm{~h}$ for patients who received cefixime, with 3.5 and $37.6 \%$ treatment failure in gatifloxacin and cefixime groups, respectively [46,48]. Dysglycemia is a major concern, for which sugar monitoring is essential [49]. Although gatifloxacin has an advantage over other quinolones, its use is banned in India.

\section{Cephalosporins}

The cephalosporins are a class of B-lactam antibiotics. Cephalosporins bind to the penicillin-binding proteins on bacteria and inhibit synthesis of the bacterial cell wall leading to cell lysis and death. With the rising DCS phenomenon, third-generation cephalosporins such as cefixime and ceftriaxone are preferred for the treatment of MDR and nalidixic acid-resistant isolates, to avoid clinical failures. As there is an increased use of cephalosporins, emergence of resistance is being observed [50-52]. Subsequently, 113 blood cultures confirmed that ceftriaxoneresistant $S$. Typhi cases have been reported from Karachi, Pakistan [53]. The mechanism of resistance is due to the production of ESBLs such as bla $a_{\mathrm{SHV}}$ and bla CTX-M-15. Prospective clinical trials assessment in Asia showed that the resistance prevalence to ceftriaxone was $0 \%$, with cure rate of $72-97 \%$ with $3-14$ days of therapy. However, the relapse rate was about $0-17 \%$, which occurred in patients treated for 7 days or less, while treatment for $8-14$ days did not show any relapses [54]. Although the route of administration of ceftriaxone is parental, it requires hospitalization and increase in healthcare costs. Cefixime is the preferred choice in developing countries due to the availability of an oral form for uncomplicated typhoid fever.

\section{Azithromycin}

Azithromycin, a member of the macrolide class of antibiotic, is an effective and convenient alternative for treating mild-to-moderate enteric fever. Clearly defined MIC breakpoints for azithromycin susceptibility have not been established, but data suggest that isolates with an MIC $\leq 16 \mu \mathrm{g} / \mathrm{ml}$ generally respond well to azithromycin and can be considered susceptible. The available clinical or pharmacokinetic/pharmacodynamic (PK/PD) data on azithromycin are limited. Notably, azithromycin nonsusceptibility rate was lower than the other agents. In Asia, analysis of 20 prospective clinical trials has proven that the relapse rate was $0 \%$ with azithromycin treatment, while the cure rate was about $81-100 \%$ with 5-7 days of therapy [55]. A study from New Delhi reported the $\mathrm{MIC}_{90}$ for $S$. Typhi and $S$. Paratyphi to be $24 \mu \mathrm{g} / \mathrm{ml}$ [40]. Following this, 34 and $38 \%$ resistance to azithromycin was reported in $S$. Typhi and $S$. Paratyphi A, respectively [55]. Recently, a case of azithromycin clinical and microbiological failure with the MIC of $4 \mu \mathrm{g} / \mathrm{ml}$ was reported from a patient with $S$. Typhi infection, from India [56]. Similarly, S. Paratyphi 
Table 3. Preferred therapy for management of typhoid fever.

\begin{tabular}{|c|c|c|c|}
\hline Antimicrobial agents & Route of administration & Children & Adult \\
\hline Ceftriaxone & $\mathrm{IM} / \mathrm{IV}$ & $50 \mathrm{mg} / \mathrm{kg}$ per day IV; for $7-10$ days & 1-2 g per day IV; for $7-10$ days \\
\hline Ciprofloxacin, levofloxacin or other $\mathrm{FQ}^{\dagger}$ & Oral/IV & - & $\begin{array}{l}\text { FQ given in full doses as recommended; } \\
\text { for } 7-10 \text { days }\end{array}$ \\
\hline Azithromycin & Oral & Used in complicated cases & $500 \mathrm{mg}$ twice a day for 5 days \\
\hline Cefixime-ofloxacin & Oral & - & 200-200 mg; for $7-14$ days \\
\hline
\end{tabular}

${ }^{\dagger}$ High-dose therapy is based on antimicrobial susceptibility profile of the infected typhoidal Salmonella strain, as majorities are nonsusceptible to quinolones. Least preferred as majority of the isolates show intermediate resistance to quinolones.

FQ: Fluoroquinolone; IM: Intramuscular; IV: Intravenous.

A with azithromycin clinical failure case with MIC of $12 \mu \mathrm{g} / \mathrm{ml}$ was reported in Australia [57]. Azithromycin is a valuable therapeutic alternative, due to higher intracellular concentrations (100-fold higher than in serum), early fever clearance rate (4-5 days), lower rates of relapse or reinfection and 5-7 days of therapy for complete cure [58]. However, azithromycin is not preferred as a monotherapy in severe typhoid, as it results in poor clinical response. Moreover, determination of MIC for azithromycin and monitoring clinical success is essential.

\section{Typhoid fever therapy: challenges in clinical practice}

For the clinical management of typhoid fever, an early initiation of effective antimicrobial therapy shortens the duration of illness, and reduces the complications and mortality. The emergence and sustained circulation of reduced fluoroquinolone susceptible $S$. Typhi, the steady rise in nalidixic acid-resistant $S$. Typhi (NARST) and cases of azithromycin treatment failure are of concern [37,56]. Typically, in these cases, a slow resolution of fever and increased risk of clinical and microbiological failure were described [59-62]. Fluoroquinolones are commonly used for treating of MDR $S$. Typhi causing uncomplicated enteric fever. The widespread use of fluoroquinolones in primary healthcare settings contributes to emergence of strains with elevated MIC to ciprofloxacin and ofloxacin across Asia and parts of Africa [63,64]. The preferred therapy for management of typhoid fever is mentioned in Table 3.

In addition to preventing weight-based dose titrations, most of these formulations also contain subtherapeutic doses of azithromycin. A review of 22 different Indian brands of fixed-dose combinations (FDCs) containing azithromycin with ofloxacin or cefixime revealed that while formulations contained an adequate fluoroquinolone or cephalosporin dose, the dose of azithromycin was $250 \mathrm{mg} /$ tablet. This quantity is one fifth of the WHO recommended dose for a $60 \mathrm{~kg}$ individual ( $1200 \mathrm{mg} ; 10 \mathrm{mg} / \mathrm{kg}$ per day). Administering five tablets of the above FDC to a $60 \mathrm{~kg}$ individual would not only result in a high pill burden and poor adherence rates but also in toxic doses of the accompanying drug.

Despite Association of Physicians of India expert advisory panel for typhoid and WHO recommendations on weight-based antimicrobial dose titration, it is possible that typhoid patients continue to be prescribed antibiotics at standard doses. For azithromycin, while dose recommendations vary between 10 and $20 \mathrm{mg} / \mathrm{kg}$ per day for 5-7 days, specific weight-based dose and therapy-duration guidelines are yet to be determined. A randomized controlled trial by Parry et al. comparing ofloxacin ( $20 \mathrm{mg} / \mathrm{kg}$ body weight per day for 7 days), azithromycin $(10 \mathrm{mg} / \mathrm{kg}$ per day for 7 days) and ofloxacin ( $15 \mathrm{mg} / \mathrm{kg}$ per day for 7 days) combined with azithromycin $(10 \mathrm{mg} / \mathrm{kg}$ per day for the first 3 days) in MDR and NARST typhoid showed that defervescence time for azithromycin-treated patients was significantly shorter than that for patients treated with ofloxacin-azithromycin and ofloxacin alone. Table 4 summarizes the studies on monotherapy and combination therapy carried out for typhoid fever management.

Fluoroquinolones and azithromycin attain better tissue penetration and kill bacteria within monocytes/macrophages more efficiently compared with third-generation cephalosporins, which primarily achieve blood stream bacterial clearance. This fact has resulted in the exploration of the possibility of combination regimens in typhoid treatment. Studies demonstrating combination therapy superiority compared with monotherapy are, however, limited. A study of 37 individuals with NARST S. paratyphi A bacteremia demonstrated that the time to fever defervescence was shorter in patients treated with ceftriaxone-azithromycin combination therapy compared with those treated with ceftriaxone monotherapy [78]. However, the significance of this finding should be confirmed with large clinical trials for its safety and efficacy. In contrast, a comparative Indian study of 62 typhoid fever patients failed to reveal a significant difference in time to defervescence between the single drug (fluoroquinolone or thirdgeneration cephalosporin) and combination drug group (fluoroquinolone with third-generation cephalosporin) [79]. 
Table 4. Controlled and noncontrolled trials on monotherapy and combination therapy for typhoid fever.

\begin{tabular}{|c|c|c|c|c|c|c|c|c|}
\hline Antibiotics & $\begin{array}{l}\text { No. of } \\
\text { patients }(n)\end{array}$ & $\begin{array}{l}\text { Study type } \\
\text { (duration of the } \\
\text { study)/location }\end{array}$ & $\begin{array}{l}\text { Dose/duration of } \\
\text { therapy (days) }\end{array}$ & $\begin{array}{l}\text { Fever } \\
\text { defervescence } \\
\text { (days) }\end{array}$ & $\begin{array}{l}\text { Clinical/ } \\
\text { microbiological failure } \\
(\%)\end{array}$ & Relapse (\%) & $\begin{array}{l}\text { Fecal } \\
\text { carriage (\%) }\end{array}$ & Ref. \\
\hline $\begin{array}{l}\text { Azithromycin vs } \\
\text { ceftriaxone (IV; } \\
\text { short course } \\
\text { therapy) }\end{array}$ & $\begin{array}{l}108 \\
\text { (children) }\end{array}$ & $\begin{array}{l}\text { Prospective } \\
\text { study } \\
(2000) / \text { Egypt }\end{array}$ & $\begin{array}{l}\text { Azithromycin } \\
10 \mathrm{mg} / \mathrm{kg} \text { per day for } 7 \\
\text { days } \\
2.5 \mathrm{~g} \text { per day for } 7 \text { days }\end{array}$ & $\begin{array}{l}\text { Azithromycin - } \\
4.1 \text { Ceftriaxone } \\
-3.9\end{array}$ & $\begin{array}{l}\text { Clinical failure: } \\
\text { Azithromycin - } 0 \\
\text { Ceftriaxone - } 19 \\
\text { Microbiological failure: } \\
\text { Azithromycin - } 0 \\
\text { Ceftriaxone - } 3\end{array}$ & $\begin{array}{l}\text { Azithromycin -0 } \\
\text { Ceftriaxone }-13\end{array}$ & NA & [65] \\
\hline $\begin{array}{l}\text { Azithromycin vs } \\
\text { ceftriaxone (IV; } \\
\text { short course } \\
\text { therapy) }\end{array}$ & 149 & $\begin{array}{l}\text { Prospective } \\
\text { study } \\
\text { (2004)/Egypt }\end{array}$ & $\begin{array}{l}\text { Azithromycin } \\
20 \mathrm{mg} / \mathrm{kg} \text { per day for } 5 \\
\text { days } \\
2.5 \mathrm{~g} \text { per day for } 5 \text { days }\end{array}$ & $\begin{array}{l}\text { Azithromycin - } \\
4.5 \text { Ceftriaxone } \\
-3.6\end{array}$ & $\begin{array}{l}\text { Clinical failure: } \\
\text { Azithromycin - } 6 \\
\text { Ceftriaxone }-3 \\
\text { Microbiological failure: } \\
\text { Azithromycin - } 3 \\
\text { Ceftriaxone }-3\end{array}$ & $\begin{array}{l}\text { Azithromycin - } 0 \\
\text { Ceftriaxone - } 17\end{array}$ & NA & [66] \\
\hline Azithromycin & $\begin{array}{l}117 \\
\text { (children) }\end{array}$ & $\begin{array}{l}\text { Open-labeled } \\
\text { noncomparative } \\
\text { study } \\
\text { (2011)/India }\end{array}$ & $\begin{array}{l}\text { Azithromycin - } \\
20 \mathrm{mg} / \mathrm{kg} \text { per day for } 6 \\
\text { days }\end{array}$ & 3.45 & $\begin{array}{l}\text { Clinical failure: } \\
\text { Azithromycin - } 6 \\
\text { Microbiological failure: } \\
\text { Azithromycin - } 15.5\end{array}$ & NA & NA & [67] \\
\hline $\begin{array}{l}\text { Azithromycin vs } \\
\text { ofloxacin }\end{array}$ & 40 (adult) & $\begin{array}{l}\text { Prospective } \\
\text { (2012)/India }\end{array}$ & $\begin{array}{l}\text { Ofloxacin }-200 \mathrm{mg} \\
\text { orally twice daily for } 7 \\
\text { days } \\
\text { Azithromycin }-1 \mathrm{~g} \text { on } \\
\text { day } 1 \text { and then } 500 \mathrm{mg} \\
\text { daily from days } 2-6\end{array}$ & $\begin{array}{l}\text { Ofloxain - } 3.68 \\
\text { Azithromycin - } \\
3.65\end{array}$ & $\begin{array}{l}\text { Clinical failure: } \\
\text { Ofloxacin-10 } \\
\text { Azithromycin-0 }\end{array}$ & No relapse & 0 & [68] \\
\hline $\begin{array}{l}\text { Ofloxacin vs } \\
\text { cefixime }\end{array}$ & 82 (children) & $\begin{array}{l}\text { Randomized } \\
\text { open trial } \\
(1995- \\
1996) / \text { Vietnam }\end{array}$ & $\begin{array}{l}\text { Ofloxacin }-10 \mathrm{mg} / \mathrm{kg} \\
\text { per day for } 5 \text { days } \\
\text { Cefixime }-20 \mathrm{mg} / \mathrm{kg} \\
\text { per day for } 7 \text { days }\end{array}$ & $\begin{array}{l}\text { Ofloxacin }-4.4 \\
\text { Cefixime }-8.5\end{array}$ & $\begin{array}{l}\text { Clinical failure: } \\
\text { Ofloxacin - } 3 \\
\text { Cefixime - } 25\end{array}$ & $\begin{array}{l}\text { Ofloxacin - } 0 \\
\text { Cefixime - } 3\end{array}$ & $\begin{array}{l}\text { Ofloxacin - } 0 \\
\text { Cefixime - } 3\end{array}$ & [69] \\
\hline Ofloxacin & 235 & $\begin{array}{l}\text { Randomized } \\
\text { open } \\
\text { study/Vietnam }\end{array}$ & $\begin{array}{l}\text { Ofloxacin }(10 \mathrm{mg} / \mathrm{kg} \\
\text { per day })-2 \text { days } \\
\text { Ofloxacin }(10 \mathrm{mg} / \mathrm{kg} \\
\text { per day }-3 \text { days }\end{array}$ & $\begin{array}{l}\text { 2-day group: } 3.8 \\
\text { 3-day group: } 4.2\end{array}$ & $\begin{array}{l}\text { Clinical failure: } \\
\text { 2-day group: } 13.5 \\
\text { 3-day group: } 7.5 \\
\text { Microbiological failure: } \\
\text { 2-day group: } 4 \\
\text { 3-day group: } 1\end{array}$ & $\begin{array}{l}\text { 2-day group: } 2 \\
\text { 3-day group: } 2\end{array}$ & NA & [70] \\
\hline $\begin{array}{l}\text { Chloramphenicol } \\
\text { vs ofloxacin }\end{array}$ & 50 & $\begin{array}{l}\text { Randomized } \\
\text { open study/Laos }\end{array}$ & $\begin{array}{l}\text { Chloramphenicol } \\
\text { ( } 50 \mathrm{mg} / \mathrm{kg} \text { per day) for } \\
14 \text { days } \\
\text { Ofloxacin }(15 \mathrm{mg} / \mathrm{kg} \\
\text { per day) }-3 \text { days }\end{array}$ & $\begin{array}{l}\text { Chloramphenicol } \\
-3.7 \\
\text { Ofloxacin-2.2 }\end{array}$ & $\begin{array}{l}\text { Clinical failure: } \\
\text { Chloramphenicol-1\% }\end{array}$ & NA & NA & [71] \\
\hline $\begin{array}{l}\text { Ofloxacin vs } \\
\text { azithromycin }\end{array}$ & 88 & $\begin{array}{l}\text { Randomized } \\
\text { control } \\
\text { study/Nepal }\end{array}$ & $\begin{array}{l}\text { Azithromycin } \\
(20 \mathrm{mg} / \mathrm{kg} \text { per day) for } \\
5 \text { days } \\
\text { Ofloxacin - ( } 8 \mathrm{mg} / \mathrm{kg} \\
\text { per day) for } 5 \text { days }\end{array}$ & $\begin{array}{l}\text { Ofloxacin - } 7 \\
\text { Azithromycin - } 5\end{array}$ & $\begin{array}{l}\text { Clinical failure: } \\
\text { Ofloxacin - } 13.6 \\
\text { Azithromycin - } 4.5 \\
\text { Microbiological failure: } \\
\text { Ofloxacin - } 4.5 \\
\text { Azithromycin - } 0\end{array}$ & $\begin{array}{l}\text { Ofloxacin - } 4.5 \\
\text { Azithromycin - } 0\end{array}$ & $\begin{array}{l}\text { Ofloxacin - } \\
41 \\
\text { Azithromycin } \\
-0\end{array}$ & [72] \\
\hline $\begin{array}{l}\text { Ofloxacin, } \\
\text { azithromycin, } \\
\text { ofloxacin } \\
\text { /azithromycin }\end{array}$ & 187 & $\begin{array}{l}\text { Randomized } \\
\text { control study } \\
(1998- \\
\text { 2002)/Vietnam }\end{array}$ & $\begin{array}{l}\text { Ofloxacin }-20 \mathrm{mg} / \mathrm{kg} \\
\text { per day for } 7 \text { days } \\
\text { Azithromycin - } \\
10 \mathrm{mg} / \mathrm{kg} \text { per day for } 7 \\
\text { days } \\
\text { Ofloxacin }(15 \mathrm{mg} / \mathrm{kg} \\
\text { per day)/azithromycin } \\
(10 \mathrm{mg} / \mathrm{kg} \text { per day) }\end{array}$ & $\begin{array}{l}\text { Ofloxacin }-8.2 \\
\text { Azithromycin - } \\
5.8 \\
\text { Ofloxacin/ } \\
\text { azithromycin - } \\
7.1\end{array}$ & $\begin{array}{l}\text { Clinical failure: } \\
\text { Ofloxacin - } 12.3 \\
\text { Azithromycin - } 18.8 \\
\text { Ofloxacin/azithromycin } \\
-6.4 \\
\text { Microbiological failure: } \\
\text { Ofloxacin - } 1.6 \\
\text { Azithromycin - 0 } \\
\text { Ofloxacin/azithromycin } \\
-1.6 \text { (patient } \\
\text { experienced } \\
\text { microbiologcal failure) }\end{array}$ & $\begin{array}{l}\text { Relapse was not } \\
\text { seen in patients } \\
\text { treated with } \\
\text { ofloxacin or } \\
\text { azithromycin or } \\
\text { ofloxacin/ } \\
\text { azithromycin }\end{array}$ & $\begin{array}{l}\text { Ofloxacin - } \\
19.4 \\
\text { Azithromycin } \\
-1.6 \\
\text { Ofloxacin/ } \\
\text { azithromycin } \\
-6.5\end{array}$ & [73] \\
\hline $\begin{array}{l}\text { Gatifloxacin vs } \\
\text { azithromycin }\end{array}$ & 287 & RCT/Vietnam & $\begin{array}{l}\text { Gatifloxacin }(10 \mathrm{mg} / \mathrm{kg} \\
\text { per day) for } 7 \text { days } \\
\text { Azithromycin } \\
\text { ( } 20 \mathrm{mg} / \mathrm{kg} \text { per day) for } \\
7 \text { days }\end{array}$ & $\begin{array}{l}\text { Gatifloxacin - } \\
4.4 \\
\text { Azithromycin - } \\
4.4\end{array}$ & $\begin{array}{l}\text { Clinical failure: } \\
\text { Gatifloxacin - } 4.3 \\
\text { Azithromycin - } 4.2 \\
\text { Microbiological failure: } \\
\text { Gatifloxacin - } 1.4 \\
\text { Azithromycin - } 2.2\end{array}$ & $\begin{array}{l}\text { Gatifloxacin - } \\
2.9 \\
\text { Azithromycin - } 0\end{array}$ & $\begin{array}{l}\text { Gatifloxacin } \\
-0.7 \\
\text { Azithromycin } \\
-0\end{array}$ & [46] \\
\hline $\begin{array}{l}\text { Gatifloxacin vs } \\
\text { cefixime }\end{array}$ & 390 & RCT/Nepal & $\begin{array}{l}\text { Gatifloxacin }(10 \mathrm{mg} / \mathrm{kg} \\
\text { per day) for } 7 \text { days } \\
\text { Cefixime }(20 \mathrm{mg} / \mathrm{kg} \\
\text { per day) for } 7 \text { days }\end{array}$ & $\begin{array}{l}\text { Gatifloxacin - } \\
3.8 \text { Cefixime - } \\
5.7\end{array}$ & $\begin{array}{l}\text { Clinical failure: } \\
\text { Gatifloxacin - } 1 \\
\text { Cefixime - } 27\end{array}$ & $\begin{array}{l}\text { Gatifloxacin - } \\
0.9 \text { Cefixime - } 3\end{array}$ & NA & [48] \\
\hline
\end{tabular}




\begin{tabular}{|c|c|c|c|c|c|c|c|c|}
\hline Antibiotics & $\begin{array}{l}\text { No. of } \\
\text { patients (n) }\end{array}$ & $\begin{array}{l}\text { Study type } \\
\text { (duration of the } \\
\text { study)/location }\end{array}$ & $\begin{array}{l}\text { Dose/duration of } \\
\text { therapy (days) }\end{array}$ & $\begin{array}{l}\text { Fever } \\
\text { defervescence } \\
\text { (days) }\end{array}$ & $\begin{array}{l}\text { Clinical/ } \\
\text { microbiological failure } \\
(\%)\end{array}$ & Relapse (\%) & $\begin{array}{l}\text { Fecal } \\
\text { carriage (\%) }\end{array}$ & Ref. \\
\hline $\begin{array}{l}\text { Gatifloxacin vs } \\
\text { chloramphenicol }\end{array}$ & 844 & RCT/Nepal & $\begin{array}{l}\text { Gatifloxacin }(10 \mathrm{mg} / \mathrm{kg} \\
\text { per day) for } 7 \text { days } \\
\text { Chloramphenicol } \\
\text { ( } 75 \mathrm{mg} / \mathrm{kg} \text { per day) for } \\
14 \text { days }\end{array}$ & & $\begin{array}{l}\text { Clinical failure: } \\
\text { Gatifloxacin - } 7 \\
\text { Chloramphenicol - } 8 \\
\text { Microbiological failure: } \\
\text { Gatifloxacin - } 1 \\
\text { Chloramphenicol - } 0\end{array}$ & $\begin{array}{l}\text { Gatifloxacin - } 2 \\
\text { Chlorampheni- } \\
\text { col - } \\
4\end{array}$ & NA & [74] \\
\hline $\begin{array}{l}\text { Gatifloxacin vs } \\
\text { ofloxacin }\end{array}$ & 627 & RCT/Nepal & $\begin{array}{l}\text { Gatifloxacin }(10 \mathrm{mg} / \mathrm{kg} \\
\text { per day) for } 7 \text { days } \\
\text { Ofloxacin }(10 \mathrm{mg} / \mathrm{kg} \\
\text { per day) for } 7 \text { days }\end{array}$ & $\begin{array}{l}\text { Gatifloxacin - } \\
3.3 \text { Ofloxacin - } \\
4.7\end{array}$ & $\begin{array}{l}\text { Clinical failure: } \\
\text { Gatifloxacin }-5 \\
\text { Ofloxacin }-7 \\
\text { Microbiological failure: } \\
\text { None }\end{array}$ & $\begin{array}{l}\text { Gatifloxacin - } 5 \\
\text { Ofloxacin - } 6\end{array}$ & NA & [75] \\
\hline $\begin{array}{l}\text { Gatifloxacin vs } \\
\text { ceftriaxone }\end{array}$ & 239 & RCT/Nepal & $\begin{array}{l}\text { Gatifloxacin }(10 \mathrm{mg} / \mathrm{kg} \\
\text { per day) for } 7 \text { days } \\
\text { Ceftriaxone }(2 \mathrm{~g} \text { per } \\
\text { day) for } 7 \text { days }\end{array}$ & $\begin{array}{l}\text { Gatifloxacin - } \\
2.43 \\
\text { Ceftriaxone - } \\
2.93\end{array}$ & $\begin{array}{l}\text { Gatifloxacin - } 15 \\
\text { Ceftriaxone }-16\end{array}$ & NA & NA & [76] \\
\hline $\begin{array}{l}\text { Azithromycin- } \\
\text { ceftriaxone } \\
\text { combination }\end{array}$ & 25 & $\begin{array}{l}\text { Prospective } \\
\text { study (2014- } \\
2015) / \text { India }\end{array}$ & $\begin{array}{l}\text { Ceftriaxone (IV) }-2 \mathrm{~g} \\
\text { daily for } 14 \text { days } \\
\text { Azithromycin }-500 \mathrm{mg} \\
\text { daily for the first } 7 \text { days }\end{array}$ & 4.8 & $\begin{array}{l}\text { Clinical and } \\
\text { microbiological failure: } \\
4\end{array}$ & No relapse & NA & [77] \\
\hline
\end{tabular}

\section{Concern in management in developing countries}

In South East Asia (SEA) and Africa, a rise in the MIC of fluoroquinolones against $S$. Typhi has shown a significant increase and is associated with longer duration of fever defervescence $[37,64,80]$. This reiterates that fluoroquinolone should not be recommended for empirical treatment of typhoid fever. Azithromycin treatment failure and emergence of cephalosporin resistance are of concern [52,56,81]. However, antimicrobial resistance to ceftriaxone/cefixime and azithromycin remains rare. In the areas where fluoroquinolone resistance is uncommon, the quinolones are the treatment of choice for all the age groups. Treatment at the maximal recommended doses $(20 \mathrm{mg} / \mathrm{kg}$ per day) for $7-10$ days has been successful in $90-95 \%$ of patients [82]. Remarkably, quinolone-resistant $S$. Typhi strains are on rise and therefore the drug of choice is limited to azithromycin or cephalosporins, which are expensive.

Randomized control trials (RCTs) of third-generation cephalosporins, primarily ceftriaxone/cefixime, in treating typhoid fever have reported an average fever clearance of 7 days, with a treatment failure rate between 5 and $10 \%$, relapse rates of $3-6 \%$ and fecal carriage of less than $3 \%[48,65,69,76]$. Similarly, RCTs on treating uncomplicated with azithromycin for 5-7 days resulted in $95 \%$ cure rate and fever defervescence of 4-6 days [46,66-68,72]. Notably, relapse rate and fecal carriage are less than $3 \%$. However, treatment with cephalosporin exhibits a slow response with a mean time of 5-7 days or an even longer duration of fever defervescence [83]. This could be attributed to poor penetration capability of the drug into cells, and thus difficulty to eradicate the bacteria from the intracellular niche. An approach of cephalosporin-azithromycin combination therapy has been suggested based on the individual pharmacokinetics [77]. The complimentary action of cephalosporins on the extracellular compartment and azithromycin on the intracellular compartment could be beneficial in treating $S$. Typhi infection.

Fixed dose combinations (FDCs) of cefixime-ofloxacin (200-200 mg) are widely used across India. With the biggest market sale of approximately $\$ 46$ million, they are increasingly available as over-the-counter prescription. An in vitro study has reported that none of the tested $S$. Typhi isolates demonstrated antagonism against this combination [84]. Some FDCs are banned for clinical use in India; these include cefixime-azithromycin, cefpodoxime-azithromycin and ofloxacin-azithromycin. Azithromycin is known to reduce cefpodoxime efficacy by PD antagonism [85]. The expert committee of the Chief Drug Advisory body of India has deemed that these FDCs are irrational. Currently, two clinical trials (clinicaltrial.gov: NCT02224040, NCT02708992) using cefixime-azithromycin and ceftriaxone-azithromycin for various indication are in progress. In the differential diagnosis of febrile illness, doxycycline plus cefixime-azithromycin is prescribed as empiric therapy, especially in SEA where rickettsial infection is common. However, drug-drug interactions showed that doxycycline decreases effects of ceftriaxone by PD antagonism [85]. There is a huge market available for these combinations in SEA and they are frequently prescribed for pelvic inflammatory infection. Greater misuse is expected with availability of this cephalosporin-azithromycin combination, which is worrisome. 
Collectively, this reiterates that in the context of reduced fluoroquinolone susceptibility, third-generation cephalosporins, such as ceftriaxone/cefixime or azithromycin, are the treatment of choice for treating $S$. Typhi in developing countries. In addition, evidence from the progressing clinical trials (clinicaltrial.gov: NCT02224040, NCT02708992), on cefixime-azithromycin and ceftriaxone-azithromycin FDCs could prove them to be be an effective alternative therapy for the management of quinolone-resistant $S$. Typhi.

\section{Natural products in treating typhoid fever}

The use of medicinal plants to treat disease is almost universal and is more affordable than purchasing expensive conventional drugs. Natural plants contain phytoconstituents containing chemical properties similar to synthetic antibiotics. Since the issues with antibiotic efficacy of monotherapy have been reported, it has become essential to evaluate biological properties of plants. Tulsi (Ocimum sanctum) has potent antibacterial activity against $S$. Typhi [FL1] [86]. An in vitro study has demonstrated significant synergy of chloramphenicol and trimethoprim with $O$. sanctum leaf extract against $S$. Typhi [86]. Similarly, acetone mango leaf extract was demonstrated with the inhibitory effect at the concentration of $10-50 \mu \mathrm{g} / \mathrm{ml}$ against MDR $S$. Typhi [87]. Nkuo-Akenji et al. have reported the lowest MIC of 0.02-0.06 $\mu \mathrm{g} / \mathrm{ml}$ against $S$. Typhi with the formulation of the methanol leaf extract of Cymbogogon citratus, Carica papaya and Zea mays silk [88,89]. Overall, studies have reported potent in vitro activity of various leaf extracts against $S$. Typhi. However, in vivo studies on the bioavailability, PK/PD, antibacterial interaction or safety profile of these natural products are limited [90]. Consequentially, defined dosage and its significant activity in treating complicated typhoid fever remain uncertain.

\section{Conclusion}

Given the emergence of fluoroquinolone and azithromycin nonsusceptible $S$. Typhi strains, it is interesting to note that there has been a recent sustained decrease in MDR typhoidal Salmonella isolates in India. This observation suggests the possible reintroduction of ampicillin, chloramphenicol and cotrimoxazole as first-line options. While these agents are inexpensive and easily available, disadvantages associated with their use include a longer duration of therapy to prevent relapses, higher relapse rates and serious adverse effects. The rate and likelihood of resistance to an antimicrobial is a function of the frequency of its use, due to the excessive selective pressure generated. It, therefore, appears likely that the decline in MDR rates would not be sustained if the abovementioned traditional first-line drugs were to be recruited into routine first-line use.

In severe cases of typhoid fever, ceftriaxone IV ( $2 \mathrm{~g}$ per day) for 10-14 days is given followed by azithromycin ( $20 \mathrm{mg} / \mathrm{kg}$ per day) for 7 days. For DCS $S$. Typhi causing uncomplicated typhoid fever, fluoroquinolone therapy is to be avoided. If necessary, higher dose of ciprofloxacin $(20 \mathrm{mg} / \mathrm{kg}$ per day) may be more effective in treating typical cases of mild typhoid fever. However, with fluoroquinolone therapy, delay in fever defervescence, relapse and faecal carriage can be expected. Therefore, treatment with azithromycin $(20 \mathrm{mg} / \mathrm{kg}$ per day) for 7 days is recommended for treating uncomplicated cases.

\section{Future perspective}

Increased use of cephalosporin or azithromycin in treating fluoroquinolone nonsusceptible $S$. Typhi may lead to a rise in cephalosporin resistance or azithromycin treatment failure. In the era of MDR, combination therapy could be an alternative for treating $S$. Typhi infection. The goal of this article is to inspire more research into the FDCs available for treatment of $S$. Typhi. In vitro combination testing of cefixime-azithromycin and ceftriaxone-azithromycin will provide detailed insights into the antimicrobial effect and drug-drug interaction of these combinations. The result of on-going clinical trials is welcomed and this could be an added value for research output. Furthermore, the extensive studies on the bioavailability, dosing, antibacterial effect, PK/PD and safety profile of natural products could reveal an alternative for antibiotics in treating $S$. Typhi infection.

Financial \& competing interests disclosure

The authors have no relevant affiliations or financial involvement with any organization or entity with a financial interest in or financial conflict with the subject matter or materials discussed in the manuscript. This includes employment, consultancies, honoraria, stock ownership or options, expert testimony, grants or patents received or pending, or royalties.

No writing assistance was utilized in the production of this manuscript. 


\section{Summary points}

- Reduced fluoroquinolones susceptibility of Salmonella enterica subsp. enterica serovar Typhi (S. Typhi) is on the rise and of significant concern in developing countries.

- Third-generation cephalosporins (cefixime, ceftriaxone) or azithromycin are the alternative for treating S. Typhi infection with decreased susceptibility to ciprofloxacin.

- An approach of cephalosporin plus azithromycin can address the shortcomings of cephalosporins including poor response and longer duration for fever defervescence.

- Cefixime-ofloxacin combination is the hugely marketed fixed-dose combination in India, for the treating S. Typhi infection.

- Evidence from the on-going clinical trials (clinicaltrial.gov: NCT02224040, NCT02708992) could be value-added information for using fixed-dose combinations, as a standard practice in treating S. Typhi, especially in Asia and parts of Africa.

\section{Authors' contributions}

AK Pragasam, YD Bakthavatchalam collected details and wrote the manuscript. B Veeraraghavan and R Ralph gave critical revision on the manuscript. All authors read and approved the final manuscript.

\section{Open access}

This work is licensed under the Creative Commons Attribution 4.0 License. To view a copy of this license, visit http://creativecomm ons.org/licenses/by/4.0/

\section{References}

Papers of special note have been highlighted as: $\bullet$ of interest; $\bullet \bullet$ of considerable interest

1. John J, Van Aart CJC, Grassly NC. The burden of typhoid and paratyphoid in India: systematic review and meta-analysis. PLoS Negl. Trop. Dis. 10(4), e0004616 (2016).

2. Parry CM, Beeching NJ. Treatment of enteric fever. BMJ 338, b1159 (2009).

3. Kalra SP, Naithani N, Mehta SR et al. current trends in the management of typhoid fever. Med. J. ArMed. Forces India. 59(2), 130-135 (2003).

4. Divyashree S, Nabarro LE, Veeraraghavan B et al. Enteric fever in India: current scenario and future directions. Trop. Med. Int. Health. 21(10), 1255-1262 (2016).

5. Rahman BA, Wasfy MO, Maksoud MA et al. Multi-drug resistance and reduced susceptibility to ciprofloxacin among Salmonella enterica serovar Typhi isolates from the Middle East and Central Asia. New Microbes New Infect. 2(4), 88-92 (2014).

6. Bhutta ZA. Current concepts in the diagnosis and treatment of typhoid fever. BMJ 333(7558), 78-82 (2006).

7. Beeching NJ, Parry CM. Outpatient treatment of patients with enteric fever. Lancet Infect. Dis. 11(6), 419-421 (2011).

- Describes the management of typhoid fever with dose and duration.

8. Parry CM, Basnyat B, Crump JA. The management of antimicrobial-resistant enteric fever. Expert Rev. Anti. Infect. Ther. 11(12), 1259-1261 (2013).

9. World Health Organization, Department of Vaccines and Biologicals. Background document: the diagnosis, treatment and prevention of typhoid fever. 19-23 (2003).www.who.int/rpc/TFGuideWHO.pdf

10. Wain J, Hosoglu S. The laboratory diagnosis of enteric fever. J. Infect. Dev. Ctries 2(6), 421-425 (2008).

11. Mogasale V, Ramani E, Mogasale VV et al. What proportion of Salmonella Typhi cases are detected by blood culture? A systematic literature review. Ann. Clin. Microbiol. Antimicrob. 15(1), 32 (2016).

12. Center for Disease Dynamics, Economics \& Policy, State of the World's Antibiotics, 2015. CDDEP, Washington, DC (2015). https://resistancemap.cddep.org/AntibioticUse.php

13. Flayhart D, Borek AP, Wakefield T et al. Comparison of BACTEC PLUS blood culture media to BacT/Alert FA blood culture media for detection of bacterial pathogens in samples containing therapeutic levels of antibiotics. J. Clin. Microbiol. 45(3), 816-821 (2007).

14. Miller NS, Rogan D, Orr BL et al. Comparison of BD Bactec Plus blood culture media to VersaTREK Redox blood culture media for detection of bacterial pathogens in simulated adult blood cultures containing therapeutic concentrations of antibiotics. J. Clin. Microbiol. 49(4), 1624-1627 (2011).

- Describes the neutralization of antimicrobial substances, which improves blood culture positivity for isolation of $S$. Typhi.

15. Mitteregger D, Barousch W, Nehr M et al. Neutralization of antimicrobial substances in new BacT/Alert FA and FN Plus blood culture bottles J. Clin. Microbiol. 51(5), 1534-1540 (2013). 
16. Keddy KH, Sooka A, Letsoalo ME et al. Sensitivity and specificity of typhoid fever rapid antibody tests for laboratory diagnosis at two sub-Saharan African sites. Bull. World Health Organ. 89(9), 640-647 (2011).

17. Kawano RL, Leano SA, Agdamag DM. Comparison of serological test kits for diagnosis of typhoid fever in the Philippines. J. Clin. Microbiol. 45(1), 246-247 (2007).

18. Wijedoru L, Mallett S, Parry CM. Rapid diagnostic tests for typhoid and paratyphoid (enteric) fever. Cochrane Database Syst. Rev. 5, CD008892 (2017).

19. Harish BN, Menezes GA. Antimicrobial resistance in typhoidal salmonellae. Indian J. Med. Microbiol. 29(3), 223-239 (2011).

20. Balaji V, Sharma A, Ranjan P et al. Revised ciprofloxacin breakpoints for Salmonella Typhi: its implications in India. Indian J. Med. Microbiol. 32(2), 161-163 (2014).

21. Raveendran R, Wattal C, Sharma A et al. High level ciprofloxacin resistance in Salmonella enterica isolated from blood. Indian J. Med. Microbiol. 26(1), 50-53 (2008).

22. Joshi S. Antibiogram of S. enterica serovar Typhi and S. enterica serovar Paratyphi A: a multi-centre study from India. WHO South East Asia J. Public Health. 1(2), 182-188 (2012).

23. Singhal L, Gupta PK, Kale P et al. Trends in antimicrobial susceptibility of Salmonella Typhi from North India (2001-2012). Indian J. Med. Microbiol. 32(2), 149-152 (2014).

24. Dutta S, Das S, Mitra U et al. Antimicrobial resistance, virulence profiles and molecular subtypes of Salmonella enterica serovars Typhi and Paratyphi A blood isolates from Kolkata, India during 2009-2013. PLoS ONE 9(8), e101347 (2014).

25. Jain S, Chugh TD. Antimicrobial resistance among blood culture isolates of Salmonella enterica in New Delhi. J. Infect. Dev. Ctries. 7(11), 788-795 (2013).

26. Shetty AK, Shetty IN, Furtado ZV et al. Antibiogram of Salmonella isolates from blood with an emphasis on nalidixic acid and chloramphenicol susceptibility in a tertiary care hospital in coastal Karnataka: a prospective study. J. Lab. Physicians 4(2), 74 (2012).

27. Menezes GA, Harish BN, Khan MA et al. Antimicrobial resistance trends in blood culture positive Salmonella Typhi isolates from Pondicherry, India, 2005-2009. Clin. Microbiol. Infect. 18(3), 239-245 (2012).

28. Muthu G, Suresh A, Sumathy G et al. Studies on antimicrobial susceptibility pattern of Salmonella isolates from Chennai, India. Int. J. Pharma. Bio. Sci. 2(2), 435-442 (2011).

29. Bhattacharya SS, Das U, Choudhury BK. Occurrence \& antibiogram of Salmonella typhi \& S. paratyphi A isolated from Rourkela, Orissa. Indian J. Med. Res. 133(4), 431 (2011).

30. Olarte J, Galindo E. Salmonella typhi resistant to chloramphenicol, ampicillin, and other antimicrobial agents: strains isolated during an extensive typhoid fever epidemic in Mexico. Antimicrob. Agents Chemother. 4(6), 597-601 (1973).

31. Wong VK, Baker S, Pickard DJ et al. Phylogeographical analysis of the dominant multidrug-resistant H58 clade of Salmonella Typhi identifies inter- and intracontinental transmission events. Nat. Genet. 47(6), 632 (2015).

32. Rodrigues C, Kapil A, Sharma A et al. Whole-genome shotgun sequencing of cephalosporin-resistant Salmonella enterica Serovar Typhi. Genome Announc. 5(10), e01639-e01616 (2017).

33. Akinyemi KO, Iwalokun BA, Oyefolu AO et al. Occurrence of extended-spectrum and AmpC $\beta$-lactamases in multiple drug resistant Salmonella isolates from clinical samples in Lagos, Nigeria. Infect. Drug Resist. 10, 19 (2017).

34. Phoba MF, Barbé B, Lunguya O et al. Salmonella enterica serovar Typhi producing Ctx-m-15 extended spectrum $\beta$-lactamase in the Democratic Republic of the Congo. Clin. Infect. Dis. 65(7), 1229-1231 (2017).

35. Sjölund-Karlsson M, Joyce K, Blickenstaff K et al. Antimicrobial susceptibility to azithromycin among Salmonella enterica isolates from the United States. Antimicrob. Agents Chemother. 55(9), 3985-3989 (2011).

36. Bethell DB, Day NPJ, Nguyen MD. Pharmacokinetics of oral and intravenous ofloxacin in multidrug-resistant typhoid fever. Antimicrob. Agents Chemother. 40, 2167-2172 (1996).

37. Parry CM, Vinh H, Chinh NT et al. The influence of reduced susceptibility to fluoroquinolones in Salmonella enterica serovar Typhi on the clinical response to ofloxacin therapy. PLoS Negl. Trop. Dis. 5(6), e1163 (2011).

38. Clinical and Laboratory Standards Institute. Performance standards for antimicrobial susceptibility testing; twenty-third informational supplement. Clinical and Laboratory Standards Institute. CLSI document M100-S23. Wayne, PA, USA (2013).

39. Clinical and Laboratory Standards Institute. Performance standards for antimicrobial susceptibility testing; twenty-second informational supplement. Clinical and Laboratory Standards Institute. CLSI document M100-S22. Wayne, PA, USA (2012).

40. Capoor MR, Nair D, Aggarwal P et al. Salmonella enterica serovar typhi: molecular analysis of strains with decreased susceptibility and resistant to ciprofloxacin in India from 2001-2003. Braz. J. Infect. Dis. 11(4), 423-425 (2007).

41. Dahiya S, Sharma P, Kumari B et al. A Characterisation of antimicrobial resistance in Salmonellae during 2014-2015 from four centres across India: an ICMR antimicrobial resistance surveillance network report. Indian J. Med. Microbiol. 35(1), 61-68 (2017).

42. Hopkins KL, Day M, Threlfall EJ. Plasmid-mediated quinolone resistance in Salmonella enterica, United Kingdom. Emerg. Infect. Dis. 14(2), 340-342 (2008).

•• Describes the plasmid-mediated quinolone-resistant gene distribution among reduced ciprofloxacin susceptible $S$. Typhi. 
43. Balaji V, Shalini A, Dhiviya Prabaa MS et al. Molecular characterization of intermediate susceptible Typhoidal Salmonella to ciprofloxacin and its impact. Mol. Diagn. Ther. 20(3), 213-219 (2016).

- Describes the advantage of using pefloxacin for screening of reduced fluoroquinolone susceptible $S$. Typhi.

44. Balaji V, Shalini A, Dhiviya Prabaa MS et al. Pefloxacin as a surrogate marker for fluoroquinolone susceptibility for Salmonella Typhi: problems and prospects. J. Clin. Diagn. Res. 10(8), DL01-DL02 (2016).

45. Sharma P, Dahiya S, Kumari B et al. Pefloxacin as a surrogate marker for quinolone susceptibility in Salmonella enterica serovars Typhi \& Paratyphi A in India. Indian J. Med. Res. 145(5), 687-692 (2017).

46. Dolecek C, Tran TPL, Nguyen NR et al. A multi-center randomised controlled trial of gatifloxacin versus azithromycin for the treatment of uncomplicated typhoid fever in children and adults in Vietnam. PLoS ONE 3(5), e2188 (2008).

47. Chau TT, Campbell JI, Galindo CM et al. Antimicrobial drug resistance of Salmonella enterica serovar typhi in asia and molecular mechanism of reduced susceptibility to the fluoroquinolones. Antimicrob. Agents Chemother. 51(12), 4315-4323 (2007).

48. Pandit A, Arjyal A, Day JN et al. An open randomized comparison of gatifloxacin versus cefixime for the treatment of uncomplicated enteric fever. PLoS ONE 2(6), e542 (2007).

49. Zvonar R. Gatifloxacin-induced dysglycemia. Am. J. Health Syst. Pharm. 63(21), 2087-2092 (2006).

50. Naveen Kumar DR, Dhiviya Prabaa MS, Baby Abirami S et al. Draft genome sequence of blaTEM-1 mediated cephalosporin resistant Salmonella Typhi from blood stream infection. J. Glob. Antimicrob. Resist. 7, 11-12 (2016).

51. Rodrigues Camilla, Kapil Arti, Sharma Anita et al. Whole-genome shotgun sequencing of cephalosporin resistant Salmonella enterica Serovar Typhi. Genome Announc. 5(10), e01639-16 (2017).

- Describes the plasmid carrying both fluoroquinolones and third-generation cephalosporins-resistant genes.

52. Klemm EJ, Shakoor S, Page AJ. et al. Emergence of an extensively drug-resistant Salmonella enterica Serovar Typhi clone harboring a promiscuous plasmid encoding resistance to fluoroquinolones and third-generation cephalosporins. MBio 9(1). pii: e00105-e00118 (2018).

53. Yousafzai MT et al. Outbreak investigation of cefriaxone resistant S. Typhi in Hyderabad, Pakistan. 10th International Conference on Typhoid and Other Invasive Salmonellosis. Kampala, Uganda, 4-6 April 2017.

54. Butler T. Treatment of typhoid fever in the 21st century: promises and shortcomings. Clin. Microbiol. Infect. Dis. 17(7), 959-963 (2011).

55. Rai S, Jain S, Prasad KN et al. Rationale of azithromycin prescribing practices for enteric fever in India. Indian J. Med. Microbiol. 30(1), 30-33 (2012).

- Describes the case of azithromycin treatment failure.

56. Manesh A, Balaji V, Kumar DRN et al. A case of clinical and microbiological failure of azithromycin therapy in Salmonella enterica serotype Typhi despite low azithromycin MIC. Int. J. Infect. Dis. 54, 62-63 (2017).

57. Fernando S, Molland JG, Gottlieb T. Failure of oral antibiotic therapy, including azithromycin, in the treatment of a recurrent breast abscess caused by Salmonella enterica serotype Paratyphi A. Pathog. Glob. Health. 106(6), 366-369 (2012).

58. Parry CM, Thieu NT, Dolecek C et al. Clinically and microbiologically derived azithromycin susceptibility breakpoints for Salmonella enterica serovars Typhi and Paratyphi A. Antimicrob. Agents Chemother. 59, 2756 (2015).

59. Chiou CS, Alam M, Kuo JC et al. Chromosome-mediated multidrug resistance in Salmonella enterica serovar Typhi. Antimicrob. Agents Chemother. 59(1), 721-723 (2015).

60. Hassing RJ, Goessens WH, Mevius DJ et al. Decreased ciprofloxacin susceptibility in Salmonella Typhi and Paratyphi infections in ill-returned travellers: the impact on clinical outcome and future treatment options. Eur. J. Clin. Microbiol. Infect. Dis. 32(10), 1295-1301 (2013).

61. Koirala S, Basnyat B, Arjyal A et al. Gatifloxacin versus ofloxacin for the treatment of uncomplicated enteric fever in Nepal: an open-label, randomized, controlled trial. PLoS Negl. Trop. Dis. 7(10), e2523 (2013).

62. Parry CM, Thompson C, Vinh H et al. Risk factors for the development of severe typhoid fever in Vietnam. BMC Infect. Dis. 14, 73 (2014).

63. Smith AM, Govender N, Keddy KH. Group for Enteric, Respiratory and Meningeal Disease Surveillance in South Africa (GERMS-SA). Quinolone-resistant Salmonella typhi in South Africa, 2003-2007. Epidemiol. Infect. 138(1), 86-90 (2010).

64. Kariuki S, Revathi G, Kiiru J et al. Typhoid in Kenya is associated with a dominant multidrug-resistant Salmonella enterica serovar Typhi haplotype that is also widespread in Southeast Asia. J. Clin. Microbiol. 48(6), 2171-2176 (2010).

65. Frenck RW, Nakhla I, Sultan Y et al. Azithromycin versus ceftriaxone for the treatment of uncomplicated typhoid fever in children. Clin. Infect. Dis. 31(5), 1134-1138 (2000).

66. Frenck RW, Mansour A, Nakhla I et al. Short-course azithromycin for the treatment of uncomplicated typhoid fever in children and adolescents. Clin. Infect. Dis. 38(7), 951-957 (2004).

67. Aggarwal A, Ghosh A, Gomber S et al. Efficacy and safety of azithromycin for uncomplicated typhoid fever: an open label non-comparative study. Indian Pediatr. 48(7), 553-556 (2011). 
68. Chandey M, Multani AS. A comparative study of efficacy and safety of azithromycin and ofloxacin in uncomplicated typhoid fever: a randomised, open labelled study. J. Clin. Diagn. Res. 6(10), 1736-1739 (2012).

69. Cao XT, Kneen R, Nguyen TA et al. A comparative study of ofloxacin and cefixime for treatment of typhoid fever in children. The Dong Nai Pediatric Center Typhoid Study Group. Pediatr. Infect. Dis J. 18(3), 245-248 (1999).

70. Vinh H, Duong NM, Phuong LT et al. Comparative trial of short-course ofloxacin for uncomplicated typhoid fever in Vietnamese children. Ann. Trop. Paediatr. 5(1), 17-22 (2005).

71. Phongmany S, Phetsouvanh R, Sisouphone $S$ et al. A randomized comparison of oral chloramphenicol versus ofloxacin in the treatment of uncomplicated typhoid fever in Laos. Trans. R. Soc. Trop. Med. Hyg. 99(6), 451-458 (2005).

72. Chinh NT, Parry CM, Ly NT et al. A randomized controlled comparison of azithromycin and ofloxacin for treatment of multidrug-resistant or nalidixic acid-resistant enteric fever. Antimicrob. Agents Chemother. 44(7), 1855-1859 (2000).

73. Parry CM, Ho VA, Phuong LT et al. Randomized controlled comparison of ofloxacin, azithromycin, and an ofloxacin-azithromycin combination for treatment of multidrug-resistant and nalidixic acid-resistant typhoid fever. Antimicrob. Agents Chemother. 51(3), 819-825 (2007).

74. Arjyal A, Basnyat B, Koirala S et al. Gatifloxacin versus chloramphenicol for uncomplicated enteric fever: an open-label, randomised, controlled trial. Lancet Infect. Dis. 11(6), 445-454 (2011).

75. Koirala S, Basnyat B, Arjyal A et al. Gatifloxacin versus ofloxacin for the treatment of uncomplicated enteric fever in Nepal: an open-label, randomized, controlled trial. PLoS Negl. Trop. Dis. 7(10), e2523 (2013).

76. Arjyal A, Basnyat B, Nhan HT et al. Gatifloxacin versus ceftriaxone for uncomplicated enteric fever in Nepal: an open-label, two-centre, randomised controlled trial. Lancet Infect. Dis. 16(5), 535-545 (2016).

77. Giri VP, Giri OP, Srivastava A et al. A clinical trial of treatment of uncomplicated typhoid fever: efficacy of ceftriaxone-azithromycin combination. Int. J. Basic Clin. Pharmacol. 4(4), 673-677 (2015).

78. Meltzer E, Stienlauf S, Leshem E et al. A large outbreak of Salmonella Paratyphi. A infection among Israeli travelers to Nepal. Clin. Infect. Dis. 58(3), 359-364 (2014).

79. Balasubramanian S, Rajeswari, Sailakshmi, Shivbalan S. Single vs multidrugtherapy in enteric fever. Indian J. Pediatr. $73(1), 103$ (2006).

80. Thompson CN, Karkey A, Dongol S et al. Treatment response in enteric fever in an era of increasing antimicrobial resistance: an individual patient data analysis of 2092 participants enrolled into 4 randomized, controlled trials in Nepal. Clin. Infect. Dis. 64(11), 1522-1531 (2017).

81. Munir T, Lodhi M, Ansari JK et al. Extended spectrum beta lactamase producing cephalosporin resistant Salmonella Typhi, reported from Rawalpindi, Pakistan. J. Pak. Med. Assoc. 66(8), 1035-1036 (2016).

82. Parry CM, Hien TT, Dougan G et al. Typhoid fever. N. Engl. J. Med. 347(22), 1770-1782 (2002).

83. Capoor MR, Nair D. Quinolone and cephalosporin resistance in enteric fever. J. Glob. Infect. Dis. 2(3), 258-262 (2010).

84. Bakthavatchalam YD, Kumar DT, Tayubi IA et al. In vitro efficacy and in silico analysis of cefixime-ofloxacin combination for Salmonella Typhi from bloodstream infection. J. Appl. Microbiol. 123(3), 615-624 (2017).

85. Preston LC (Ed.). Stockley's drug interactions. (2015). www.medicines-complete.com

86. Mandal S, Mandal MD, Pal NK. Enhancing chloramphenicol and trimethoprim in vitro activity by Ocimum sanctum Linn. (Lamiaceae) leaf extract against Salmonella enterica serovar Typhi. Asian Pac. J. Trop. Med. 5, 220-224 (2012).

87. Hannan A, Asghar S, Naeem T et al. Antibacterial effect of mango (Mangifera indica Linn.) leaf extract against antibiotic sensitive and multi-drug resistant Salmonella Typhi. Pak. J. Pharm. Sci. 26(4), 715-719 (2013).

88. Nkuo-Akenji T, Ndip R, McThomas A et al. Anti-Salmonella activity of medicinal plants from Cameroon. Cent. Afr. J. Med. 47, $155-158$ (2001).

89. Efunwole O, Adetuberu I, Oladipupo A et al. Antibacterial effect of Carica papaya against Salmonella Typhi, causative agent of Typhoid fever. IOSR-JESTFT 12(4), 1-6 (2018).

90. Chattopadhyay D, Ojha D, Mukherjee H et al. Validation of a traditional preparation against multi-drug resistant Salmonella Typhi and its protective efficacy in S. Typhimurium infected mice. BioMed. Pharmacother. 99, 286-289 (2018). 